\author{
Maryana Yaroshevych \\ PhD Student of the Department of Economic and Social Geography \\ e-mail: maryana-ya@ukr.net, ORCID ID: https://orcid.org/0000-0002-5057-4905 \\ Ivan Franko Lviv National University, P. Doroshenka str., 41, Lviv, 79000, Ukraine
}

\title{
EASTERN EUROPEAN GAS HUB IN EUROPEAN GAS HUBS SYSTEM
}

There are the questions considered in the article which have prospect of creation on the basis of the Ukrainian underground gas storages of the powerful East European gas regulator (hub) that will be capable to increase the level of energy security of Ukraine, liberalize domestic market of natural gas and to integrate into the European system of gas pipelines and to provide profitability of underground gas storages of the country. The development of the gas sector of Ukraine is a priority in the context of the implementation of Ukraine's European integration plans in the economic sphere and is determined not only by the geographical location but also by the technological integration of the gas transportation infrastructure in the European economic space over the past decades. The entry of the Ukrainian natural gas market into the European gas market system will contribute to: enhancement of Ukraine's energy security; improving the quality and level of relations between Ukraine and the EU countries in cooperation on the gas markets of Central and Eastern Europe; creating a favorable investment climate for the further development of the gas transmission system. Whereas the European experience, it can be argued that underground storages create a powerful base for the formation and further operation of the East European gas hub from a transport and logistics point of view.

Keywords: geographical location, social location, economical location, gas hub, gas storage. $\boldsymbol{X A \boldsymbol { B } I \boldsymbol { B }}$

Мар'яна Ярошевич. СХІДНОЕВРОПЕЙСЬКИЙ ГАЗОВИЙ ХАБ У СИСТЕМІ СВРОПЕЙСЬКИХ ГАЗОВИХ

Метою роботи є висвітлення важливих географічних передумов формування проектованого Східноєвропейського газового хабу та його конкурентоспроможності на газовому ринку Європи. У статті розглянено географічне положення як важливу логістичну перевагу при формуванні Східноєвропейського газового хабу. Розглянено одні із основних об'єктів газотранспортної інфраструктури - газові сховища, на базі яких повинен сформуватись майбутній український газовий хаб. Проаналізовано основні параметри функціонування газових сховищ. Вивчено європейський досвід функціонування газових хабів. Проведено аналіз функціонування газових хабів Німеччини та їх зв'язок з газосховищами країни. У найбільшій мірі у даній праці використовуються конкретнонаукові методи, а саме метод аналізу аналогових ареалів, оскільки проводиться дослідження об'єктів - газових хабів шляхом їх співставлення і метод порівняння. Також застосовується картографічний метод для наочного висвітлення досліджуваної проблематики.

Ключові слова: географічне положення, суспільно-географічне положення, економіко-географічне положення, газовий хаб, газове сховище. \section{ХАБОВ}

Марьяна Ярошевич. ВОСТОЧНОЕВРОПЕЙСКИЙ ГАЗОВЫЙ ХАБ В СИСТЕМЕ ЕВРОПЕЙСКИХ ГАЗОВЫХ

Целью работы является освещение важных географических аспектов формирования проектируемого Восточноевропейского газового хаба и его конкурентоспособности на газовом рынке Европы. В статье рассмотрено географическое положение как важное логистическое преимущество при формировании Восточноевропейского газового хаба. Рассмотрено одни из основных объектов газотранспортной инфраструктуры - газовые хранилища, на базе которых должен сформироваться будущий украинский газовый хаб. Проанализированы основные параметры функционирования газовых хранилищ. Изучено европейский опыт функционирования газовых хабов. Проведен анализ функционирования газовых хабов Германии и их связь с газохранилищами страны. В наибольшей степени в данной работе используются конкретно научные методы, а именно метод анализа аналоговых ареалов, поскольку проводится исследование объектов - газовых хабов путем их сопоставления и метод сравнения. Также применяется картографический метод, для наглядного освещения исследуемой проблематики.

Ключевые слова: географическое положение, социально-географическое положение, экономико-географическое положение, газовый хаб, газовое хранилище.

Problem statement. The Eastern European gas hub is one of the largest energy projects that can liberalize the natural gas market, integrate the Ukrainian gas transport system into a European gas pipeline system and ensure the profitability of underground gas storage facilities in the country. The relevance of a research subject consists in the need of socio-geographical study of transport and energy problems of our country.

Main part. The concept of geographical location is one of the main categories in geography. Geographical location refers to the location of an object or area of the earth's surface in relation to other objects or territories that are located outside the boundaries of this object or area and have an effect on them. Geographic location is a dynamic description that constantly acquires new features and changes with the varying properties of the geographical object and its interactions with other objects.

Academician S. Rudnytskyi writes in his work "Galicia and United Ukraine": "Geographic location is, perhaps, the most important geographical factor for each land-based unit: the continent or a complex of countries, land or neighbourhoods, even a single locality." [1, p. 379]. By considering this issue it is also worth to pay attention to the transport research of a scientist. Despite the fact that economic, including transport and communications, was not of main focus problem of the 
scientific activities, S. Rudnytsky adequately examined it in several of his scientific works. The most complete economic-geographical description of Ukraine is given in the work "Ukraine: Land und Volk" (Ukraine: Country and Nation) (1916). Prior to that, in the work "Short Geography of Ukraine", the scientist gave a description of the paths year of 1914, and in the paper "The Ukrainian case on the state of political geography" (1923), where the one third is "The Ukrainian case on the part of the economic", the economic and geographical issues are reviewed, and also the connection between transport and the political situation is traced. In general, the transport geography S. Rudnytsky enlisted in the economic geography, which, accordingly, is the branch of anthropogeography. Then, when a scientist wrote about Ukraine, her territory was distributed between Russia, Poland and Romania. In particular, S. Rudnytsky often mentioned the territory that passed to Poland: "... Ukraine lost its independence, was annexed to Poland, fell into the position of a large and rich and recklessly used colony ..." [1, p. 188].

Prof. Shabliy O. notes that " the geographical location is the spatial relation of a particular object (country, city, mountain range, etc.) to geographical particularities that lie outside it and have or may have a significant influence on it" [3, p. 93]. The structure of geographical location allocates subsystems - socioeconomic, cultural and ethno cultural location. The scientist refers "geographical location" to difficult category as it always individualizes a geographical object. The geographical location displays such features as positionality and uniqueness. According to the scientist, the geographical position - is the property of the object, but at the same time it reflects its relation to other territorial systems. The approach to the definition of socio-geographical location completely preserves the features of determining the geographical location. Socio-geographical location is interpreted as the position of a certain sociogeographical object in relation to other objects that have economic significance for it (sources of energy, transport routes, etc.). Prof. Topchiyev O. in his work "Fundamentals of human geography" describes the relationship and interaction of geographical object with other objects as an important characteristic that affects its further development. The scientist notes that the spatial relationship of the object to other neighbours is a relative tie, but is used by geographers more often, because it enables to carry out a comprehensive description of the spatial organization: "... the theory and practice of sociogeographical research convincingly testify that it is analysis of relative locations, the study of the neighbourhood allows to give the placement of individual objects a profound and meaningful qualitative characteristic" [2, p. 154-155].

There are few scientific papers which consider the topic of the gas hubs. In year 2010 Patrick Heather published his paper "The Evolution and Functioning of the Traded Gas Market in Britain" which described the genesis and development of Britain's traded gas market for which the political and financial imperatives of the early 1980 's, as much as the desire to create a competitive market, were a key factor. The Heather's paper "Continental European Gas Hubs: Are they fit to purpose?" provides a comprehensive and timely review of gas market developments against the backdrop of the ongoing transition from long term oil-indexed contracts to hub based contracts. In anticipation of this transition reaching its logical conclusion, the question in the paper's title i.e. "are the European gas hubs fit for purpose?" relates to the ability of the hubs to provide a reliable basis for hub-based pricing in long term contracts. After studying the development in trading liquidity and the close correlation of prices between the hubs, the answer from this paper is an emphatic 'yes' although the exact roles of the individual hubs will probably continue to differ. Based on extensive research and discussion with the key actors intimately involved, the paper provides deep insights into the characteristics of the individual hubs, the reasons behind their particular evolutionary path and the prospects for their further development [6].

We consider a transport geographical location as a subsystem of an economic geographical location, the study of which draws attention to the infrastructure components of transport systems. Speaking about a specific object - the East European gas hub, firstly, it is necessary to localize separate structural elements - gas storage facilities. There are are 5 underground gas storages facilities in western region of Ukraine - Uherske, Oparske, Bilche-Volitsko-Uherske, Dashavske and Bogorodchanske (Fig. 1). The largest one is Bilche-Volitsko-Uherske with an active capacity of 17050 million cubic meters (Table 1).

The main characteristics of underground gas storages in the western region of Ukraine

\begin{tabular}{|l|c|c|c|}
\hline \multicolumn{1}{|c|}{ Gas storage } & $\begin{array}{c}\text { Active capacity, } \\
\text { million } \mathbf{~ m}^{\mathbf{3}}\end{array}$ & $\begin{array}{c}\text { The capacity that is used, } \\
\text { million } \mathbf{~}^{\mathbf{3}} \\
\mathbf{2 6 . 0 9 . 2 0 1 7}\end{array}$ & $\begin{array}{c}\text { Percentage of use, } \\
\mathbf{\%}\end{array}$ \\
\hline Bilche-Volitsko-Uherske & 17050 & 8240 & 48,33 \\
\hline Bogorodchanske & 2300 & 1700 & 73,91 \\
\hline Dashavske & 2150 & 1753 & 81,53 \\
\hline Oparske & 1920 & 591 & 30,78 \\
\hline Uherske & 1900 & 540 & 28,42 \\
\hline
\end{tabular}


This gas storage should become the core of the future projected hub. The next largest is Bogorodchanske 2300 million cubic meters, Dashavske - 2150 million cubic meters, Oparske - 1920 million cubic meters, and Uherske - 1900 million cubic meters [5]. All gas storage facilities in the western region have the same genesis: they appeared on the site of exhausted gas / oil fields. It should also be noted that gas storage facilities, especially the first four, are located in short distances from each other. This allows us to talk about them as about one structured geographic object. The five above-mentioned gas storage facilities are almost identical to the location of the Oleska shale gas deposit in the Western region of Ukraine with a total area of $6,324 \mathrm{~km}^{2}$. The Oleska shale gas deposit is located on the territory of Lviv area (Busk, Zhidachiv, Zhovkiv, Zolochiv, Kamianka-Buzky, Mykolayiv, Peremyshlyansky, Pustomyty, Sokal districts), Ivano-Frankivsk area (Tlumatsky, Galitsky, Gorodenkivsky, Rogatinsky districts) and the extreme western part of Ternopil area (Fig. 1).

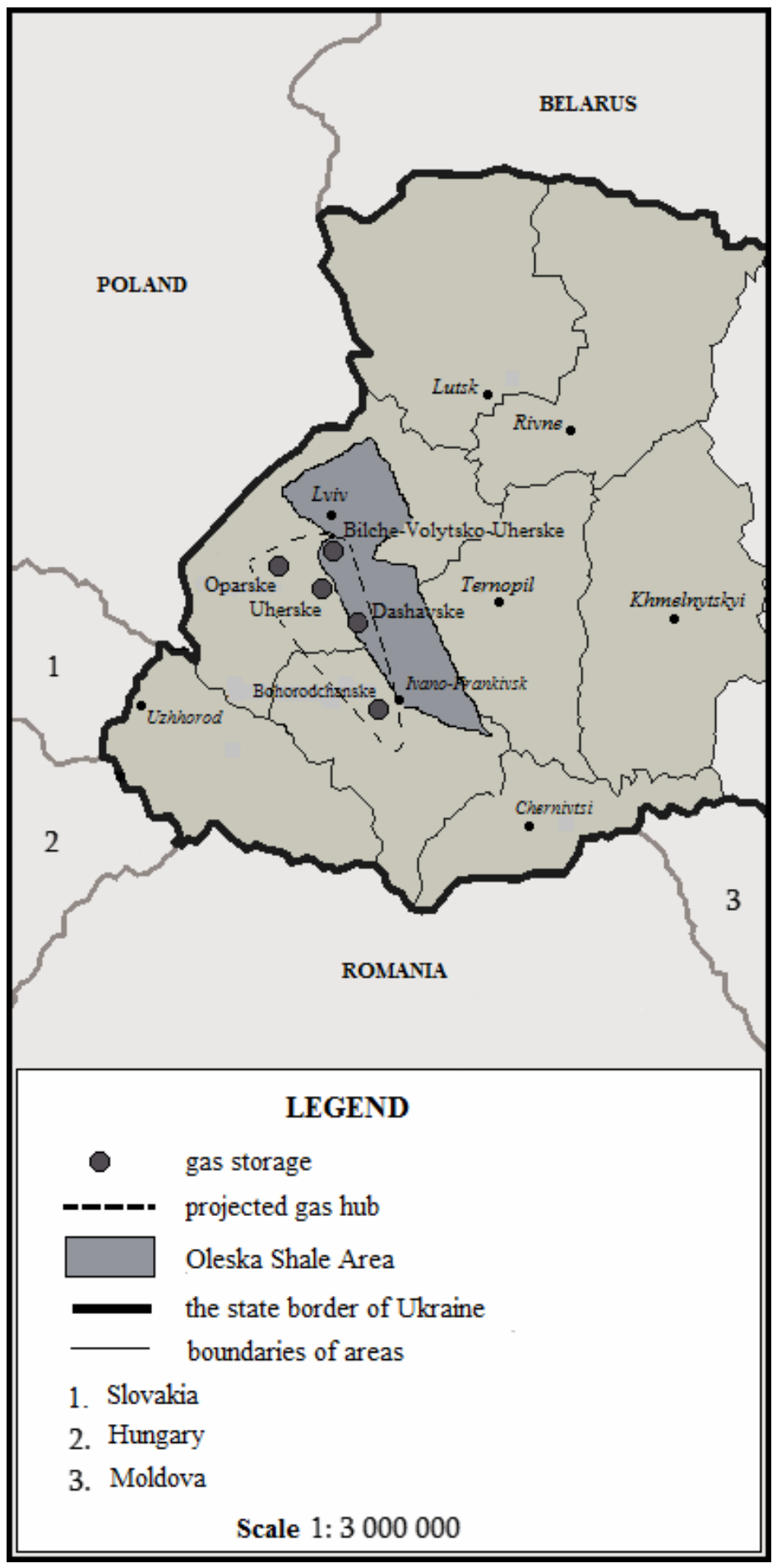

Fig. 1. Underground gas storage in the western region of Ukraine 
Except five underground gas storages (UGS) of the western region there are eight more in Ukraine. Seven of them are located on eastern region of the country, along important transport and pipeline points (and also Glebovske in the territory of occupied Crimea). The facilities of Chervonopartizanske gas storage (total capacity is 2700 million cubic meters) and Olischivske gas storage (total capacity is 660 million cubic meters) are natural reservoirs based on the aquifer structure. All other gas storages, like gas storage facilities in the western region, are created on the site of former gas / oil fields. The gas storage facilities have the following capacity: Proletarske - 4800 million cubic meters, Solo- hivske - 2000 million cubic meters, Kehichevske 1,315 million cubic meters, Verhunske - 920 million cubic meters, Krasnopolivske - 800 million cubic meters [5]. These gas storage facilities are generally used for internal needs of the country in general and of the region in particular. Generally the Ukrainian gas storage system is one of the worlds largest and the most powerful in Europe (Table 2). In recent years Ukraine uses only up to $50 \%$ of capacity of gas storages. According to Naftogaz, the company has started a project to forecast demand for the use of gas storages and to explore the possibility of increasing the active capacity of systems.

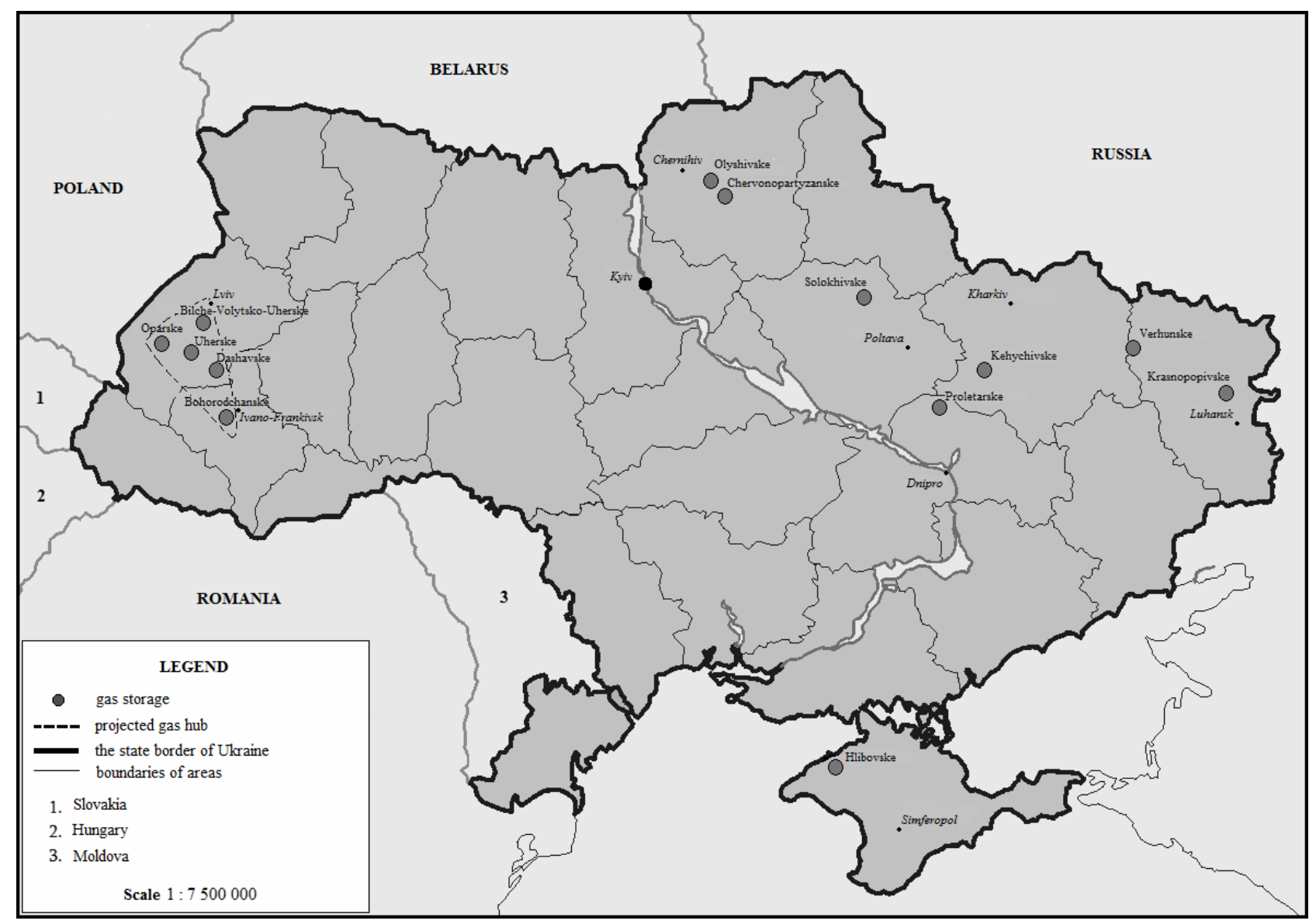

Fig. 2. Underground gas storage facilities of Ukraine

Table 2

Indicators of the use of gas storage in Europe

\begin{tabular}{|l|c|c|c|}
\hline \multicolumn{1}{|c|}{ Country } & $\begin{array}{c}\text { General capacity, } \\
\text { million } \mathbf{m}^{\mathbf{3}}\end{array}$ & $\begin{array}{c}\text { Reserves of natural gas } \\
\text { in storages, million } \mathbf{m}^{\mathbf{3}} \\
\boldsymbol{*} \mathbf{1 0 . 0 4 . 2 0 1 7}\end{array}$ & $\begin{array}{c}\text { Percentage of use, } \\
\mathbf{\%}\end{array}$ \\
\hline Ukraine & 30950 & 8304 & 26,8 \\
\hline Germany & 22627 & 6680 & 29,5 \\
\hline Italy & 18445 & 7630 & 41,4 \\
\hline France & 12855 & 2898 & 22,5 \\
\hline Netherlands & 13338 & 2270 & 17,0 \\
\hline Austria & 1463 & 8773 & 16,7 \\
\hline
\end{tabular}


The geographic remoteness of the gas storage facilities of the western region of Ukraine from other gas storages of the country not only strengthens logistic positions, but also makes possible to consider the aggregate of gas systems as a gas hub of the European model. That is why, we can say about the formation of an East European gas hub in the western region of Ukraine.

It should be noted that desire to keep competition through development of standard and legal base in a background of the general economic crisis at the European political level has caused fast development of a number of the European gas hubs which influence pricing of the gas. Classification of the European gas hubs on trading, transit and transition is the most widely used The British hub NBP (National Balancing Point) and the Netherlands TTF (Title Transfer Facility) belong to the main of trading hubs. Whilst NBP is still by far the most active traded hub in Europe, its lead over TTF is slowly diminishing. This is mainly due to increased volumes on the Dutch market whereas the British market has been more modest in its volume development [6]. Generally the trade hubs have the greatest influence on gas pricing. The largest transit hubs in Europe are the Belgian ZEE (Zeebrugge) and the Central European Gas Hub (CEGH).

The main purpose of transit gas hubs is to facilitate the process of transferring large quantities of gas for further distribution among consumers. In fact, transit hubs are physical points where market participants can trade. Indeed, the two transit gas hubs of North West Europe, Zeebrugge in Belgium and Baumgarten in Austria have the capacity between them to handle around $45 \%$ of the demand in the downstream countries they provide gas to. This makes these two locations very important in the physical context of gas deliveries to Western Europe. However, the nature of their formation means that trading has not developed as much as in neighbouring hubs [6]. Transition hubs are the German GPL (Gaspool Balancing Services hub) and NCG (NetConnect Germany), the French PEGs (The Points d'Echange de Gaz), and the Italian PSV (The Punto di Scambio Virtuale). In general, this category includes hubs that have already managed to declare their position on the market, liberalize it by trading, but have not yet fully revealed their potential. There is reason to believe that the projected East European gas hub will be the largest competition for the Central European gas hub, since, first of all, the geographically closest to it, and, secondly, has considerably more potential in terms of capacity of gas reservoirs, which will enable to develop in the future a powerful market a gas trading platform. In order to ensure the security of gas supply on a regional basis and avoid the problem of energy dependence, the European Commission proposes to create nine zones of gas supply with the relevant regulations, and thus strengthen ties and cooperation between market participants (Fig. 3).

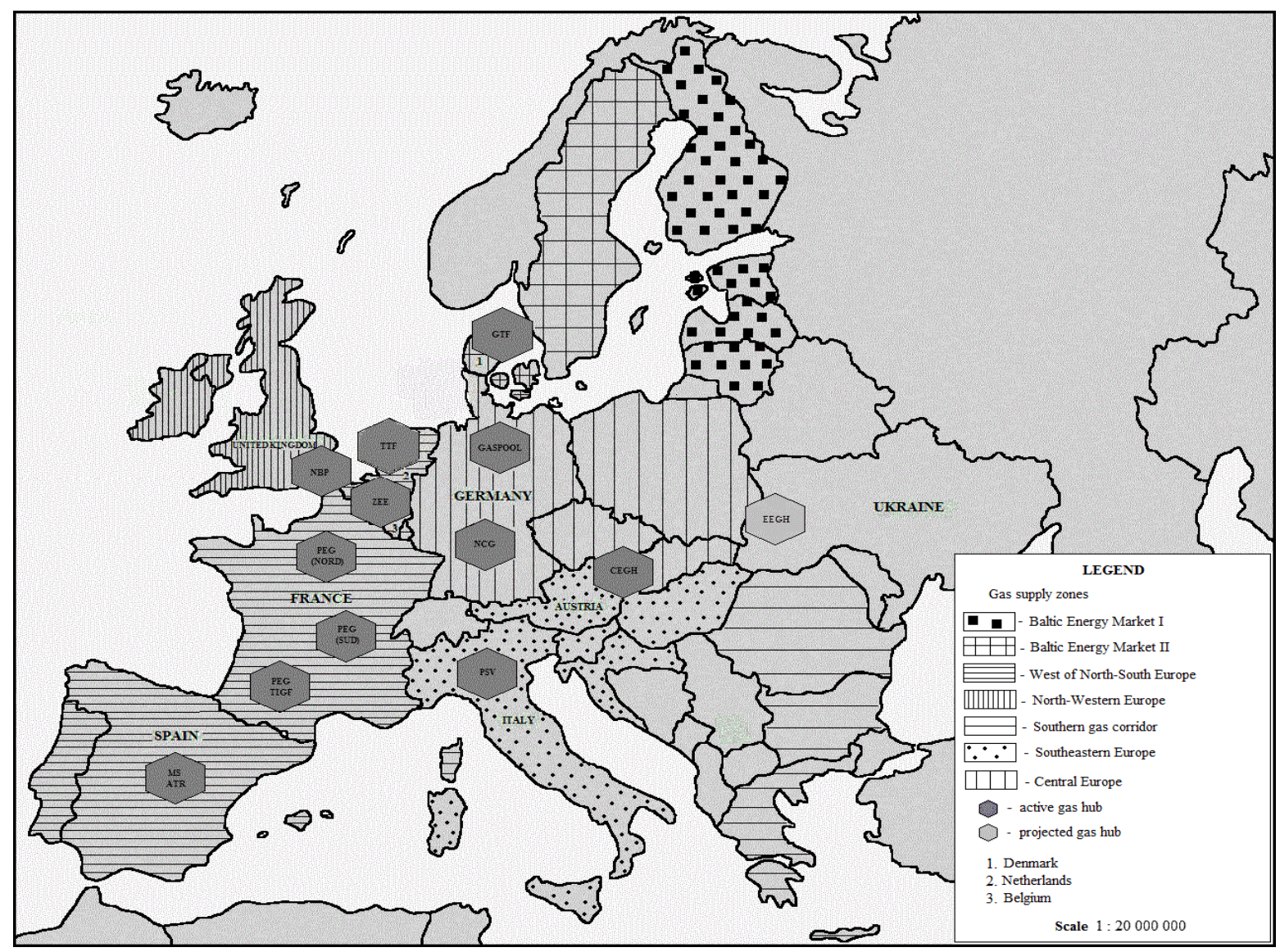

Fig. 3. Gas supply zones and gas hubs in Europe 
The countries of each zone will share responsibility for the formation of strategic gas reserves and the development of gas infrastructure. According to this regionalization, the following gas supply areas should be distinguished: North-Western Europe, West of North-South Europe, Central Europe, Baltic Energy Market I, Baltic Energy Market II, Southeastern Europe, Southern gas corridor and separate islands Malta and Cyprus. The principle of solidarity between countries is also regulated, in which neighboring states should assist each other during the crisis with gas supplies and ensure the work continuity of certain sectors of industry and agriculture that are most dependent on gas. In coordination with the European Commission, states should also share responsibility for the development of gas infrastructure and the formation of strategic gas reserves. Particular attention is also paid to the creation of reverse supplies between countries. This should be kept in mind by designing the Eastern European gas hub. Despite Ukraine's direct borderline with the Eastern gas monopoly, from November 25, 2015, Ukraine imports natural gas only from its western neighbors. In 2016, Ukraine received the main resource of imported gas from Slovakia (9 billion cubic meters). Approximately 1 billion cubic meters were also imported from Poland and Hungary. Such change in gas supply policy was caused by several factors, the most important of which is the unresolved issue of the relationship between the companies of «Gazprom» and «Naftogaz» Ukraine [8].

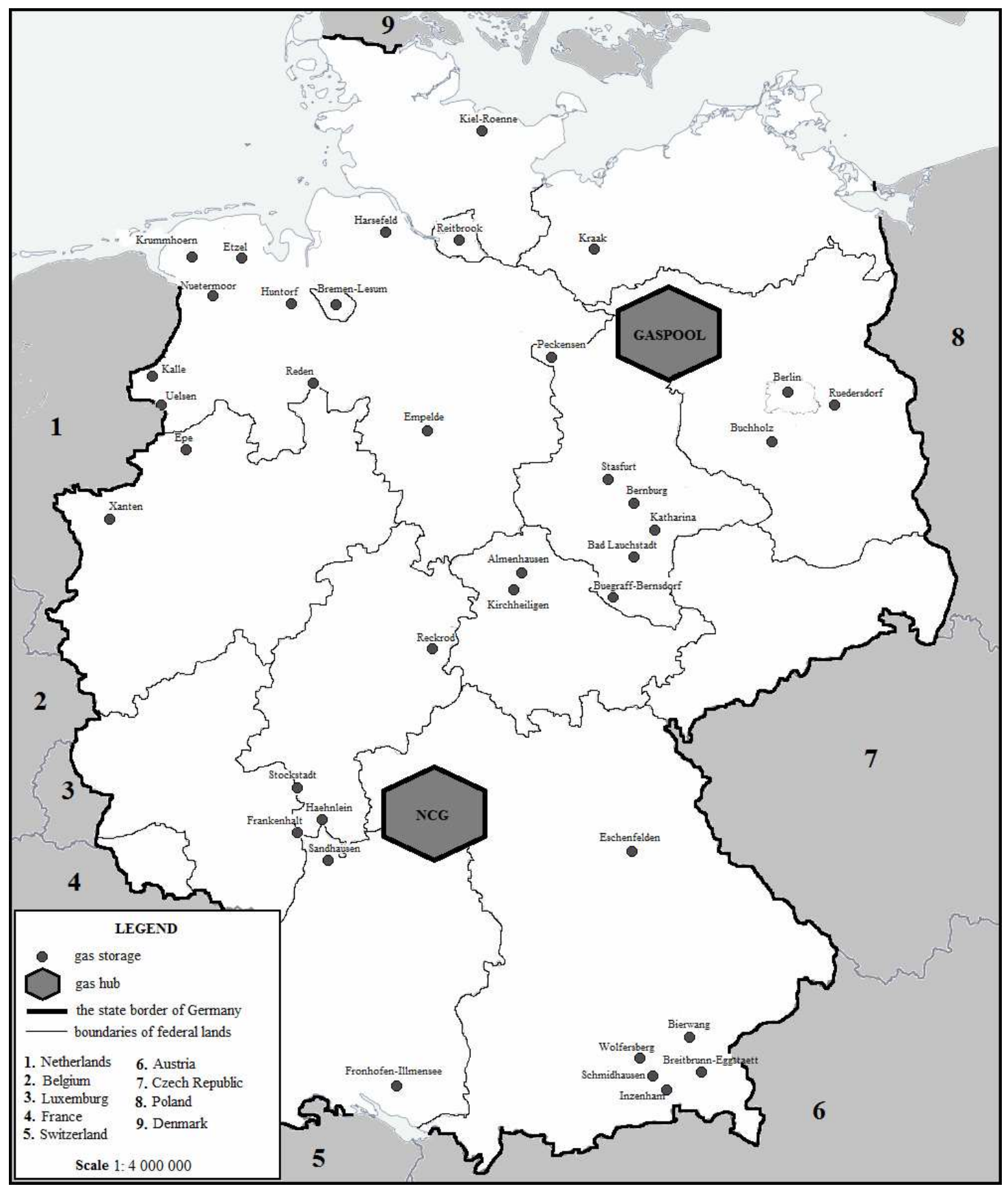

Fig. 4. Gas storage and hubs of Germany 
It is also worth noting that the share of the state companies in import of gas has decreased in favor of private importers whom in the market there are more than 20. European companies have wary of the Ukrainian market, but there is a noticeable positive dynamic. For example, «Naftogaz» and Polish «PGNiG» have signed the contract for urgent supply of gas in March 2018 after the Russian monopolist «Gazprom» has refused to deliver gas to Ukraine. The contract is valid until the end of March 2018. The volume of the contract is more than 60 million cubic meters. Deliveries are implemented on the Hermanowice point connects the Polish and Ukrainian gas transportation systems. Despite all the risks that currently exist on the Ukrainian gas market, at the end of 2017 it became known about the start of work of foreign companies directly in Ukraine. Today there are four European traders who supply gas to the domestic market although the volumes are still rather small. But it says about positive dynamics in the process of liberalization of the Ukrainian gas market. To study the aspects of the functioning of the East European gas hub, it is important to discover European experience in this field. One of the greatest gas storage systems is in Germany. There are 51 gas storage facilities in the country with the total capacity of gas reservoirs, as noted earlier, about 22627 million cubic meters. Two gas hubs were formed on the basis of developed gas infrastructure: Gaspool in the north and NCG in the south of the country (Fig. 4). Both gas hubs are marketplaces and are not geographically tied to gas storages, but are rather a virtual point formed at the intersection of gas transport corridors, where the most active way is the distribution of energy between market participants. In the case of Ukraine, the gas storages of the western region provide extraordinary manoeuvrability of gas flows, optimization of the operating modes of the energy sector, as well as the creation of necessary operational and strategic gas reserves, which is important in the context of market relations. All these preconditions can serve as a powerful base for the creation of a European gas hub in Ukraine

Summary. As an example of the German experience in the field of gas hub formation, one can conclude that powerful gas platforms can be formed regardless of the location of gas storage facilities. But their close location can be a significant advantage and become the basis for the formation and operation of a gas hub. It can be also concluded that on the basis of gas storage facilities in the western region of Ukraine it is possible to form a powerful gas hub of the European model. To develop a model of the Ukrainian hub, the feasibility study needs to be implemented for the creation of a suitable gas field and the development of a related infrastructure, identifying sources of financing for the hub and listing issues that require appropriate changes to the current legislation. The next step should be market research in market sphere to determine the circle of stakeholders on the activities of the gas hub (domestic and foreign), working out the issue of the creation and operation of the working body of the gas hub, etc.

\section{References:}

1. Rudnytskyi, S. (1994). Halychyna ta soborna Ukraina [Galicia and united Ukraine]. Chomu my khochemo samostiinoi Ukrainy? - Why we want independent Ukraine? Lviv: Svit [in Ukrainian].

2. Topchiev, O.H. (2001). Osnovy suspilnoi geografii [Fundamentals of human geography]. Odesa: Astroprynt, 560 [in Ukrainian].

3. Shabliy, O.I. (2012). Osnovy suspilnoi geografii [Fundamentals of human geography]. Lviv: VTS LNU im. I. Franka, 295 [in Ukrainian].

4. Yaroshevych, M.A. (2015). Suspilno-geografine polozhennya Skhidnoevropeiskoho hazovoho khabu [Social and economical aspects of East European Gas Hub`s location]. Region-2015: suspilno-geografichni aspekty: Materialy mizhnarodnoi naukovo-praktychnoi konferentsii studentiv, aspirantiv ta molodykh naukovtsiv - Region-2015: socail and economical aspects: Materials of international scientific conference for students, PhD students and young scientists. Kharkiv: KhNU im. V.N. Karazina, 36-38 [in Ukrainian].

5. Chernova, O.T. (2014). Analiz rozvytku merezhi pidzemnykh skhovyshch hazu Ukrainy [Analysis of the network of underground gas storage facilities Ukraine]. Rozrobka rodovyshch - Mining, 8, 261-276. Retrieved from http://mining.in.ua/articles/volume8_3/34.pdf [in Ukrainian].

6. Heather, P. (2012). Continental European Gas Hubs: Are they fit to purpose? The Oxford Institute for Energy Studies. June 2012. Retrieved from https:/www.oxfordenergy.org/wpcms/wp-content/uploads/2012/06/NG-63.pdf [in English].

7. Karta gazovykh skhovyshch [Storage map] (2015). Gazova infrastruktura Evropy - Gas infrastructure Europe. Retrieved from http://www.gie.eu/index.php/maps-data/gse-storage-map [in Ukrainian].

8. Rozyednannia [Unbundling] Dzerkalo tuzhnya. Retrieved from http://gazeta.dt.ua/energy_market/unbundlingrozdiliti-nak-naftogaz-ukrayini-mozhna-ale-hto-voloditime-yiyi-chastinami-ta-v-chiyih-interesah-_.html [in Ukrainian]. 